\section{PP-193 Oxalate Absorption is Blocked by Prior Administration of Calcium in Rats}

Department of Urology, Faculty of Medicine, University of the Ryukyus, Okinawa, Japan

Rayhan Zubair Hossain, Makoto Morozumi

Kimio Sugaya, Tadashi Hatano. Yoshihide Ogawa

Male rats were divided into 6 groups of 6 animals each, and were administered normal saline (group 1), a $10 \mathrm{mg}$ dose of oxalate (group 2), $10 \mathrm{mg}$ of oxalate immediately prior to equimolar calcium (group 3 ), $10 \mathrm{mg}$ of oxalate immediately after equimolar calcium (group 4), $10 \mathrm{mg}$ of oxalate 30 minutes prior to equimolar calcium (group 5 ), or $10 \mathrm{mg}$ of oxalate 30 minutes after equimolar calcium (group 6). Urine samples were collected at hourly intervals up to 5 hours, and urinary oxalate, calcium, magnesium, and phosphorus were measured. The cumulative urinary increment of oxalate over 5 hours was $2.00 \mathrm{mg}, 0.79 \mathrm{mg}, 0.30 \mathrm{mg}, 0.72 \mathrm{mg}$, and $0.67 \mathrm{mg}$ in group $2,3.4$, 5 , and 6 , respectively. Oxalate absorption was maximum in group 2 $(20 \%)$, and was minimum in group $4(3 \%)$. Urinary calcium excretion showed a decrease in group 2 . This study demonstrated that, calcium could help to prevent or minimize oxalate absorption and urinary oxalate excretion, if it was ingested just before an oxalate rich meal. Therefore, calcium should always be taken earlier than oxalate in order to decrease the oxalate absorption.

Oxalate absorption Urinary oxalate excretion Oral calcium load

\section{PP-194 上部消化管におけるシュウ酸吸収部位の 検討}

\section{琉球大学 医学部 泌尿器科}

諸角 誠人, Rayhan Zubair Hossain, 西島 さおう

菅谷 公男, 秦野 直, 小川 由英

目的:シュウ酸吸収部位として、胃、小腸の関与を調べるため。 対象および方法:Wistar 系雄性ラット(約 180g) 30 匹を 6 群 に分け使用した。夷験群はシュウ酸 $10 \mathrm{mg}(110 \mu \mathrm{M})$ 胃投与 群、幽門部結禁後ーシュウ酸 $10 \mathrm{mg}$ 胃投与群、幽門部結紮後 ーシュウ酸 $10 \mathrm{mg}$ 十二指腸投与群、シュウ酸 $10 \mathrm{mg}(110 \mu \mathrm{M})$ 十カルシウム $4.4 \mathrm{mg}(110 \mu \mathrm{M})$ 胃投与群、幽門部結禁後ーシュ ウ酸 $10 \mathrm{mg}(110 \mu \mathrm{M})+$ +カルウム $4.4 \mathrm{mg}(110 \mu \mathrm{M})$ 胃投与群、 幽門部結禁後ーシュウ酸 $10 \mathrm{mg}(110 \mu \mathrm{M})+$ +カルシム $4.4 \mathrm{mg}$ $(110 \mu \mathrm{M})+$ 二指腸投与群の 6 群とした。開始前、1、2、3、4、5 時間後にそれぞれ採尿し、尿中シュウ酸、グリコール酸および クエン酸はキャピラリー電気泳動にて、また、尿中カルシウム、 マグネシウムおよびリンは ICP 分光光度計にて測定した。結 果:いずれも 1 時間後尿より尿中シュウ酸排泄量の増加を認 めた。特に十二指腸投与群において著しく増加した。尿中カル シウム排泄量に有意差を認めなかった。考案:シュウ酸は全消 化管より吸収されるといわれ、Hautmannの報告同様、胃にお けるシュウ酸吸収が確認された。また、シュウ酸吸収における 主要部位は、小腸あるいは大腸であることが示唆された。 シュウ酸 上部消化管 シュウ酸吸収部位
PP-195 xanthine oxidase inhibitorsによる落酸 および葆酸カルシウム結晶による細胞障 害能および COM 結晶の細胞付着能の抑 制

\begin{abstract}
慶應義塾大学" 稲城市立病院 ${ }^{21}$
長㤗 克己 ${ }^{12}$, 朝倉 博孝"1, 松崎 章二 ${ }^{21}$, 丸茂 健", 村井 勝" [目的]葆酸および COM 結晶による紐胞障害は尿路結石発生因子の一つとし て注目され、この細胞障害は xanthine oxidase 阻害薬により防くことができると いう。加、 xanthine oxidase 阻害菜の cell-crystal interactionに及ほ寸影 響については知られて挹ず、本研究では、xanthine oxidase 阻害薬による COM 結晶による細胞障害能や結晶付着能に対する抑制勃果について梌討し た。
\end{abstract}

【方法|MDCK、LLCPK, および HK-2紐胞を confluent とL、0.2 mmol と2 mmol のアロプリノールまたはオキシプリノールの存在下に、 KOx および KOx+ COM 結晶を加え 4 時間反応させ、その細胞障害能を測定した。COM 結晶付 着能の検討は、 $0.2 \mathrm{mmol}$ と $2 \mathrm{mmol}$ のアロプリノールとオキシプリノールを 4 時

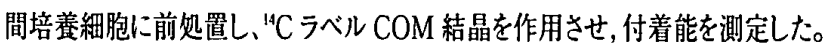
【成績|アロプリノールおよびオキシプリノールは、それぞれ葆酸かウムおよび葆 酸カルシウム結晶の絊胞障害能を抑制したままた、アロプリールおよびオキシプ リノールは、碞度依存性に葆酸カルシウム結晶の細胞付着能を抑制した。 【結論】アロプリノールおよびオキシプリノールは、苳酸および葆酸かルシウム結晶 による細胞障害能拈び COM 結晶の細胞付着能を抑制した。この結果は、 xanthine oxidase 阻害菜が、尿路結石症の治療薬として期待できる新たな知 見と考えられた。

尿路結石症 細盷障害 アロプリノール

\section{PP-196 腎上皮細胞一葆酸カルシウム結晶相互作 用におけるクエン酸・マグネシウムの効果 について}

\section{旭川医科大学 医学部 泌尿器科” 遠軽厚生病院 泌尿器科2}

加藤 祐司", 山口 聡", 高下 紀子", 岩田 達也"

八竹 直", 奥山 光彦", 西原 正幸"

【目的】葆酸カルシウム結晶の形成・成長・凝集における低分子抑制物質と して、尿中クエン酸、マグネシウムが知られているが、腎上皮細胞への接着 に及ほす影響については、ほとんど検討されていない。われわれは、葆酸力 ルシウム結晶と腎上皮細胞との相互作用に抽て、クエン酸およびマグネ シウムの細胞一結晶間の接着に対する抑制効果を検討する。【方法】C ラベルされた葆酸カルシウム 1 水和物結晶( $\mathrm{C}^{19}-\mathrm{COM}$ 結晶)を作成し、 種々の源度の塩化マグネシウム、クエン酸 1 水和物水溶夜と $\mathrm{C}^{\mathrm{H}}-\mathrm{COM}$ 結 晶を、培盖したMDCK 細胞に作用させた。夜体シンチレーションカウンター で $\mathrm{C}^{14}-\mathrm{COM}$ 結晶と細胞の結合度を測定し、結晶-細胞間の接着におけ るクエン酸、マグネシウムの影響を比較検討する。また、高葆酸尿の実験乇 デルとして、MDCK 細胞を葆酸曝露により細胞障害を惹起させ、C $C^{14}$ COM 結晶の接着およびその際のクエン碐とマグネシウムの影響を検討す る。結果・考察了葆酸カルシウム結石形成に関しては近年、堅培養細胞を 用いた細胞一結晶間相互作用が注目されている。本実験系により，従来結 石形成を抑制するとされる低分子物質の腎上皮紐胞と苳酸カルシウム結 晶の接着に及ほすす影㗽を検討し、クエン酸およびマグネシウムの苳酸カル シウム結石の再発予防としての新たな機序について追求したい。 紐胞結晶間相互作用 低分子物質 クエン酸・マグネシウム 